\title{
WORK-TO-FAMILY SPILLOVER: GENDER DIFFERENCES \\ IN HUNGARY ${ }^{1}$
}

\section{Márta Radó - Beáta Nagy - Gábor Király}

\section{ABSTRACT}

It is crucial to understand the role that labor market positions might play in creating gender differences in work-life balance. One theoretical approach to understanding this relationship is the spillover theory. The spillover theory argues that an individual's life domains are integrated; meaning that well-being can be transmitted between life domains. Based on data collected in Hungary in 2014, this paper shows that work-to-family spillover does not affect both genders the same way. The effect of work on family life tends to be more negative for women than for men. Two explanations have been formulated in order to understand this gender inequality. According to the findings of the analysis, gender is conditionally independent of spillover if financial status and flexibility of work are also incorporated into the analysis. This means that the relative disadvantage for women in terms of spillover can be attributed to their lower financial status and their relatively low access to flexible jobs. In other words, the gender inequalities in work-to-family spillover are deeply affected by individual labor market positions. The observation of the labor market's effect on work-life balance is especially important in Hungary since Hungary has one

\footnotetext{
${ }^{1}$ This paper has been prepared as part of a Hungarian Scientific Research Fund project Dilemmas and strategies in reconciling family and work (OTKA K104707); Márta Radó has also been supported by the joint Research Excellence Award of the Hungarian National Bank and Corvinus University of Budapest.

Literature searching in databases and the registration of records in a spreadsheet, as well as downloading and saving the full text articles were done by a group of committed undergraduate students, namely Dávid Ádám, Yvette Lovas and Bence Pálóczi. The authors of this paper are extremely grateful for their help and effort.
} 
of the least flexible labor arrangements in Europe. A marginal log-linear model, which is a method for categorical multivariate analysis, has been applied in this analysis.

Keywords: work-life balance, spillover, flexibility, well-being, gender, Hungary

Márta Radó

Corvinus University of Budapest MTA TK "Lendület" Research Center for Educational and Network Studies (RECENS)

E-mail: Rado.Marta@tk.mta.hu

Beáta Nagy

Corvinus University of Budapest

E-mail: beata.nagy@uni-corvinus.hu

Gábor Király

Budapest Business School, Corvinus University of Budapest

E-mail: gabor.kiraly@uni-corvinus.hu 


\section{INTRODUCTION}

The increasing feminization of the labor market has called attention to the issue of work-life balance in both academic and policy-related investigations. In the early years of research the emerging clashes between work and private life were emphasized, while later publications also found positive relationships between the two (Powell and Greenhaus, 2010). This paper investigates the effects of paid work on family life and the issue of how various work-related characteristics influence family life. We first introduce the key theoretical concepts concerning work-family balance, as well as the spillover phenomenon. In the second section of the paper, we discuss some of the recent research findings on spillover, gender and flexibility. We then introduce the most important characteristics of these factors as they occur in the Hungarian context. Drawing on this empirical and contextual background, the authors attempt to analyze spillover effects in the Hungarian context, based on a nationally representative dataset from a survey conducted in May 2014.

\section{BASIC CONCEPTS OF WORK-LIFE INTERFACE}

For a long time most of the empirical findings focusing on the relationship between work and private life was interpreted in the framework of conflict and segmentation theories. These accounts highlighted the differing and conflicting characteristics of these spheres (Greenhaus and Beutell, 1985). Moving away from the simple conflict approach, Roehling and her colleagues (2003) constructed three different models to describe the relationship between working and nonworking life spheres. These frameworks were the compensation, segmentation and spillover models. Compensation theory states that dissatisfaction or failure in one area might be compensated for by satisfaction and success in another area; the segmentation theory focuses on keeping the emotions and stress factors of these two spheres independent from one another. These models also assume that there is no overlap or connection between work life and the private life. Contrary to this, spillover theory claims that experiences in one sphere influence the other sphere, and some authors, like Roehling et al. (2003), certainly reference the positive relationship between the two spheres.

For the last few decades the research focus has shifted considerably towards the quality of interactions, very often to the question of positive effects in the work-to-family relationship. The new theories, utilizing various concepts 
like positive spillover, modified the perspective of the issue. Researchers have argued that work life and family life interact with each other, i.e. both positive and negative spillover can be present in people's lives, and they interact in both directions (work-to-family and family-to-work), and that the two fields are more often allies than enemies, with the effects reinforcing one another instead of competing with one another (Roehling et al., 2003; Greenhaus and Powell, 2006). Depending on the character of research questions and concepts, different theories are applicable in the research setting (Dén-Nagy, 2013). The next section will discuss the spillover theory in detail.

\section{SPILLOVER THEORIES}

Spillover theories can be identified by their holistic character, covering various interactions between work and family life (Tammelin, 2009 offers a detailed summary). Theauthors of this paper share the basic insights of this approach, namely, that emotions, values, attitudes, behaviors and skills are the basic components 'travelling' between the spheres (llies et al. 2009; Tammelin, 2009; Powell and Greenhaus, 2010). Spillover, however, means much more than a simple cause-andeffect influence from one sphere to the other, but rather the phenomenon that "activities in one role can benefit an individual's activity in another role" (Grzywacz et al. 2007, p.561). As illustrated in the following paragraphs, different theoretical approaches are similar with regards to presupposing a 'polarity' for spillover effects (either negative or positive), and different in terms of paying attention to different elements 'travelling' between spheres. Below, we briefly summarize the main approaches examining these effects.

Edwards and Rothbard (2000) noted that due to the spillover process, strong connections between work and family life are observable, and similarities are generated. If negative moods and emotions, like fatigue, are simply brought by a person from one domain to the other, it can be labelled as work-family conflict signaling incompatibility, but if they generate similarities between these two life domains, we can call them negative work-to-family spillover (Rantanen, 2008, p.15).

Edwards and Rothbard (2000) provided more hints regarding the content of these similarities in the two fields, which also served as a basis for their analysis: "These similarities usually are described in terms of work and family affect (i.e., mood and satisfaction), values (i.e., the importance ascribed to work and family pursuits), skills, and overt behaviors" (Edwards and Rothbard, 
2000, p.180). Based on these categories, the articles usually distinguish affective and instrumental work-family spillover (Greenhaus and Powell, 2006).

Affective work-family spillover means that people bring home work-related moods or attitudes. Both moods and attitudes belong to affective spillover; but mood is more diffuse, whereas attitude is more stable and long lasting (llies et al. 2009). In addition to the affective work-family spillover, researchers' theories also refer to the transfer of skills from one domain to another, often called instrumental spillover. (For a short summary see Table 1 in the Appendix.)

Recently, Powell and Greenhaus (2010) also applied this dual approach (affective and instrumental spillover) while referring to Hanson et al. (2006), who gave the following examples for providing a better understanding of spillover: "Individuals experience affective positive spillover when they transfer positive affect (e.g., positive mood or happiness) from one domain to the other domain. Individuals experience instrumental spillover when they transfer values (e.g., embracing diversity), skills (e.g., using Excel spreadsheets), and behaviors (e.g., acting ethically) acquired or nurtured in one domain to the other domain" (quoted by Powell and Greenhaus, 2010, p.518).

Theoretical considerations described above demonstrate that there are widely shared ideas about the spillover concept. All theories reviewed underline the growing importance of a spillover approach in empirical investigations. These features will be further discussed in the next section focusing on recent empirical research findings.

\section{EMPIRICAL INVESTIGATIONS ON WORK-FAMILY SPILLOVER ${ }^{2}$}

As illustrated above, spillover theory has different facets according to the different areas of its application, as well as to the various disciplines in which the concept is utilized. This is also mirrored in the richness and diversity of the empirical literature related to the construct. In this section we focus on two interrelated issues in connection with the analysis of this paper. First, we discuss job flexibility in general, then we will review the relationship between gender and flexibility in particular.

\footnotetext{
${ }^{2}$ This short empirical review section only discusses papers directly analyzing those factors which are also utilised in this paper. Detailed and systematic empirical reviews on spillover effects can be found at the papers of Greenhaus and Powell (2006) and Király et al. (2015).
} 
Among the articles collected from the literature search, the issue of flexibility was particularly strong. While job and organizational flexibility can considerably help workers in reconciling their job and home responsibilities, it can also impede workers in establishing and managing boundaries between their life spheres. Keeping this dual aspect of the phenomenon in mind, findings will be presented according to whether they positively affected or were ambivalent/critical about flexibility.

Numerous papers argue that workplace flexibility can have a positive effect on employees' lives by decreasing negative spillover and contributing to the perception of a higher level of work-life balance. For example, Jung Jang and colleagues (2012) found that having flexible schedules decreased employee stress in general. Nevertheless, they also emphasized that specific groups such as women, single parents, and those who are heavily burdened by family responsibilities can benefit more from organizational flexibility measures (Jung Jang et al. 2012). In line with these results, Lourel and colleagues (2009) highlight that work-life balance policies can lead to a higher level of organizational commitment among employees. Based on 18 semi-structured interviews, the Pedersen and Jeppesen (2012) also pointed to the fact that flexible scheduling can contribute to work-life enrichment by assisting employees in their attempts to manage their boundaries between life-spheres.

Nevertheless, a significant number of research articles emphasize the ambivalence and/or negative aspects related to flexible working arrangements. Fursman and Zodgekar (2009), for instance, highlighted the point that choosing flexible working conditions can hinder the career prospects of employees (Fursman and Zodgekar, 2009, p.53). Moreover, Joyce and colleagues showed that flexibility policies representing organizational interests (i.e. fixed term contracts, involuntary part time employment) could be detrimental to employee health (Joyce et al. 2010).

Powell and Greenhaus (2010) wrote one of the most comprehensive papers as far as gender and spillover effects are concerned. Investigating fulltime managers and professionals in the American population, they explicitly distinguished sex and gender in their analysis. According to their results, people who scored higher in femininity (personality traits such as interpersonal and communal orientation) also experienced higher levels of positive spillover. Moreover, those who were higher on family role salience (importance of the individual's role in the family) showed lower levels of conflict between work and family (Powell and Greenhaus, 2010, pp.525-529).

Offer (2014) investigated gender differences in parents' mental labor (planning, organization and management of everyday activities) and the amount 
of emotional stress involved. The author emphasizes in one of the key findings that both mothers and fathers are equally likely to think about family matters, however, these mental activities only generate stress in the case of mothers, harming their emotional well-being and not the father's (Offer, 2014, pp.932-933). Furthermore, Keene and Reynolds (2005) examined married Americans who were employed in order to reveal how family and workplace factors influenced gender differences in negative family-to-work spillover. The results showed that women were twice as likely to have the experience that family demands are detrimental to their workplace performance (family-to-work spillover) (Keene and Reynolds, 2005, pp.293-294).

Primecz and colleagues (2014) conducted an extensive qualitative research project using both focus groups and interviews to examine employees at so called employee-friendly organizations in Hungary. Investigating representatives of key roles (such as HR managers) and members at various levels of the organizational hierarchy, they could point to inequalities tied to both gender and organizational positions. While flexible work schedules are primarily offered to employees with small children, these are primarily aimed at mothers. These women experienced considerable time pressure when working part time in theory only, since they regularly 'checked in' from home after their kids went to sleep (at night) or before they got up (in the morning). Fathers with children are rarely even considered employees needing any help to reconcile work and family responsibilities. Moreover, researchers emphasize that even if fathers contributed to the caring responsibilities, often they are responsible for regular and plannable activities (such as children' sport's training sessions), while mothers are the ones who have to deal with unexpected and 'emergency' situations (Primecz et al. 2014, p.11).

Primecz and her colleagues also emphasize, however, that mothers with young children cannot be considered a homogenous group since women in executive positions could control their work schedule, the commuting time, and the location of their work - even to the point of affecting the direction in which the company should move - to a much greater extent than the rest of their employees. This meant that they could benefit more from their company's employee friendliness while other women faced more of the negative aspects of being a working woman. This particular research shed light on the delicately interwoven nature of gender and organizational inequalities (Primecz et al. 2014, p.12).

The next part of the paper further elaborates on the previously discussed middle-range work-life balance theories, and explores the factors influencing the spillover of employees in the present Hungarian context. 


\section{THE HUNGARIAN CONTEXT}

During the state-socialist era women and men were treated equally in political rhetoric, however, in reality, the gender wage gap was similar to that in western countries, and the patterns of occupational segregation were even more pronounced (Csillag, 2007). After the transition to capitalism, both men's and women's employment opportunities dropped dramatically in Hungary, and stabilized at a very low level. Between 2001 and the recession in 2008, employment rates started increasing across Europe, however, the pace of growth was much more intense in the old member states than in the new ones, thanks to the employment policy in place at the time. The economic recession further increased the gap between the old and new member states' employment rates, particularly for men, and then austerity measures hit women's employment opportunities severely (Fodor and Nagy, 2014). Currently women's employment rates are 55.9 percent in Hungary, compared to the European Union (EU) average of 59.7\% (Eurostat, 2015a).

In our analysis, we utilize two types of variables concerning flexible jobs: flextime (understood as a flexible work schedule) and flexiplace for working remotely. The access to flexible working arrangements is also substantially lower in the Central and Eastern European (CEE) countries than in the old EU member countries. Medgyesi (2001) argues that the reason Hungary lags behind in flexible work arrangements is two-fold. Firstly, the employment and social policies were less concerned with motivating employers to create flexible work arrangements. This attitude is clearly apparent in the regulation of parental leave, during which one of the parents (usually the mother) is encouraged to leave the labor market completely instead of working part-time. Second, Hungarians have rather instrumental attitudes as far as work as a social activity is concerned. More specifically, having a secure and/or well-paying job is considered much more important than having a flexible one. It means that the most important thing for Hungarians is security (62\%) and salary (56\%), whereas flexible working hours are important only for $23 \%$ of employed individuals (Róbert, 2008, cited by TÁRKI, 2010, p.5).

The flexibility of work schedules can be measured in the proportion of part time jobs, overwork, flexible working hours, and the length of working time. Part time employment was very low, 5\% in Hungary, while it was 17.5\% for the EU28 countries in 2015. This index is higher for females (7.3\%) than for males (4.1\%) in Hungary. However, gender differences are much more pronounced in the EU28, where this index is $8.8 \%$ for males and $32.2 \%$ for females (Eurostat, 2015b). It is noteworthy that most part-time work is comprised of low paying jobs of poor quality and of jobs requiring a high level of qualification (Medgyesi, 2001). 
Another way to understand flexible work schedules is to observe the length of working time. In the old member states the individualized working hours' arrangement is widespread, whereas in the new member states the traditional 40-hour working week is still the dominant pattern. Hungary, even among CEE countries, has an exceedingly high proportion of people working 40 hours a week. More than $80 \%$ of employed people belong to this group (Plantenga and Remery, 2009). It is important to reiterate that flexibility in working time is related to financial status since these working arrangements are more likely to characterize the situation of the lowest and the highest earners (TÁRKI, 2010). Thus, it is important to note that the concept of flexibility is ambiguous, as it might contain both constraints and opportunities. Our analysis will refer to the latter one.

In the investigation on which this paper is based, the other observed indicator of flexibility of work is the availability of flexiplace. This is usually measured by the incidence of telecommuting or working from home. Similarly to what was found to be true of part time jobs, Hungary drops behind when compared to Western European countries in terms of this indicator as well, however, the gap between the old and new member states is not as wide as was the case concerning the flexibility of working time (for example, telecommuting is widespread in the Czech Republic). Based on the fourth European Working Conditions Survey (2007), 8.3\% of the respondents in the EU27 countries said that their job involved telecommuting at least for a quarter of their time, whereas this index was only $3.6 \%$ in Hungary. Flexibility of the location of work differs from flexibility of working time in two other respects. First, men tend to have more flexibility in terms of choosing the location of their work activities than females. Secondly, usually people of higher social status (more well-educated, white collar workers etc.) might have jobs that do not require a constant presence at the place of work (contrary to a factory worker, for example) hence their work can be done from home (Hárs and Neumann, 2008).

Another dimension that needs to be reviewed is the problem of unpaid jobs, since gender differences are more articulated in unpaid than in paid work. In Hungary, women still overwhelmingly take the burden of household chores compared to men. Moreover, women of poorer families tend to do even more housework than well-off families. As a result, women are more likely to feel the time pressure, which indicates work-family conflicts. TÁRKI (2010) identifies long working hours as one of the main reasons why women generally have more work-family conflict. This paper also pointed out that working part-time could decrease this conflict. 


\section{EMPIRICAL ANALYSIS}

The following empirical analysis is based on a sociological investigation carried out by TÁRKI as part of its monthly Omnibus survey in May 2014. The questionnaire was designed by the research group of the Centre for Gender and Culture at the Corvinus University of Budapest. The sample is representative of the Hungarian adult population by gender, age, type of settlement, and educational level, and consists of 1007 people. The working sample contains those who were employed or self-employed at the time of the survey, therefore 514 persons worked, and the rest of the respondents were inactive or unemployed. Six respondents have not answered for one of the key variables, therefore, 508 responses are analyzed in the following section.

\section{Description of variables}

This present analysis focuses exclusively on the work-to-family interactions at the micro level, since, according to the literature, spillover research focuses the most on this level. Because we would like to relate our findings to these results, we also concentrated on these types of interactions. There might be different ways to measure spillover with both quantitative and qualitative approaches, so an index was calculated comprising both the quantitative and qualitative aspects of spillover. This index was based on items that measure both negative and positive spillover effects. Since spillover in general cannot be captured by one question, certain domains of spillover were measured and these results were aggregated. We should also emphasize that the groups are clearly subjective indicators, which are partly determined by each individual's subjective evaluation, not merely by the objective effect of one life domain on the other. The following questions (see Table 1) are used to calculate this workto-family spillover index.

First, we created an index containing these items. By multiplying by -1 the results of items measuring negative influence between spheres auxiliary variables were created. A spillover index was then calculated by getting the standardized sum of positive items and auxiliary variables. This index takes on a higher value if work has a larger effect on family. The Cronbach's alpha is 0.7 , which validates the reliability of the index. 
Table 1: Items measuring negative and positive work-to-family spillovers

$\begin{array}{lll}\text { Negative spillover } & 1 & \begin{array}{l}\text { How often do you think about work-related problems when } \\ \text { you are not working? }\end{array} \\ \text { items } & 2 & \begin{array}{l}\text { How often are you too stressed out at home to enjoy family life } \\ \text { due to work-related problems? }\end{array} \\ \text { Positive spillover } & \text { How often do you feel that you cannot see your family or } \\ \text { items } & 4 & \begin{array}{l}\text { How often do you feel you get on better at home due to work } \\ \text { related success? }\end{array} \\ & 5 & \text { How often can you utilize the skills acquired at your workplace? } \\ & 6 & \begin{array}{l}\text { How often is the atmosphere of your family life positively } \\ \text { affected by having a good mood at work? }\end{array}\end{array}$

Finally, this spillover variable was recoded as a categorical variable taking on three values (henceforth indicated as spillover). This variable takes on a value of 1 when someone falls below the bottom $33 \%$ of the population, a value of 2 when the given person falls below the second third, and a value of 3 when the given person falls under the top 33\% of the spillover index. In other words, the spillover index takes on value of 1 when someone has a negative spillover compared to the average, takes on a value of 2 when someone has an average level of spillover, and finally takes on a value of 3 when the given person has a positive level of spillover. In this study, spillover is the dependent variable.

For the analysis, financial status, gender and flexibility of work were chosen as independent variables. Table 2 in the Appendix shows the distribution of the independent variables in the working population. Financial status was measured by the subjective evaluation of the income level of the household. It is important to mention that wealth was not measured as individual financial situation but as the subjective financial situation of the respondent's household. Although, we are well aware that there is a limitation in extrapolating these data at the individual level, we still utilize this as a proxy variable, keeping the limitations of this method in mind. First, this is because gaining objective data through questionnaires about wages is highly problematic due to the potentially high frequency of non-response, so using subjective data might be more fruitful in this situation. Secondly, because of the wage gap, if a woman lives in a low-income household, it is much more likely that she also belongs to 
the poorly paid section of the working population than the other way around. As a result, subjective well-being was measured by the following sentence:

"How would you rate your own financial well-being?"

1 I am in financial need.

2 I have financial difficulties from month to month.

3 My monthly salary is just enough for living.

4 By planning ahead I get along well.

5 I do not have any financial problems.

Based on this question, two categories were distinguished: (1) those who have financial problems or whose salary is just enough to live on, and (2) those who cope well. Table 3 in the Appendix shows the distribution of financial wellbeing by gender.

The analysis also takes into account the flexibility of the work, because most of the previous research findings emphasized its crucial role concerning work-life balance. We can distinguish two kinds of flexibility, as described above. We work with the type of flexibility that captures the more positive aspects. This variable takes on a value of 2 when the given person had neither flexible working times nor a flexible workplace, and it takes on a value of 1 when either the working time or the workplace is flexible. Flexibility of the workplace was measured by the following question: "My work can be done anywhere. How much is this statement valid for your work?" The flexibility of work time was measured by the following question: "Flexible work time. How much is it valid for your work?". Table 4 in the Appendix presents the distribution of flexibility of work by gender and financial status. The variable of gender takes on a value of 1 if the respondent is male and 2 if this person is female.

The age variable takes on a value of 1 if the respondent is between 18 and 25 years of age, a value of 2 if this person is between 26 and 35 years old, a value of 3 if this person is between 36 and 49 years old, and a value of 4 if this person is 50 years old or older.

\section{Methodology}

We have applied marginal log-linear models in this paper, and they have enabled us to conduct a multivariate analysis with categorical data. This permits not only a two-dimensional analysis, but also takes into account certain confounding variables. The application of a categorical data analysis was also beneficial due 
to the low sample size that would not allow complex multivariate analysis with many of the variables and several categories. The aim of this paper, therefore, is to capture a simple structure between certain variables. This methodology is also in line with our exploratory type of research questions, which were not designed to explore a linear relationship, but rather aimed at observing how different predictors influence the risk categories of spillover. ${ }^{3}$ We only briefly introduce the statistical background of the marginal log-linear models.

The general log-linear representation of a $2 \times 2$ contingency table is an additive parameterization of logarithm of cell frequencies,

$$
\ln \mu_{i j}=\lambda_{0}^{A B}+\lambda_{i}^{A}+\lambda_{j}^{B}+\lambda_{i j}^{A B}
$$

where the $\lambda_{0}^{A B}$ is called as overall effect, $\lambda_{i}^{A}$ is the effect of category i of $A$, $\lambda_{j}^{B}$ is the effect of category j of $\mathrm{B}$ and $\lambda_{i j}^{A B}$ is the interaction effect of category i of $A$ and category $\mathrm{j}$ of $\mathrm{B}$. In the same way more dimensional parameters can be included to the model. In case of general log-linear parameters $\left(\lambda_{L}^{V}\right)$ the superscript of the parameter ( $V$ ) shows all the observed variables, whereas the subcript $(L)$ includes a subset of the complete set of variables. $\lambda_{L}^{V}$ parameter represents the effect of the variables which are in the downer index $(L)$ controlled for the variables which are included in the upper index, but not included in the lower index $(V-L)$.

General log-linear parameters always include a complete set of variables in the analysis. In certain cases the researcher does not want to use all the observed variables in the analysis. For example, in case of a longitudinal analysis the researcher may not want to explain a dependent variable which was measured in the second wave by a variable from the third wave. In this case one might use marginal log-linear parameters $\left(\lambda_{L}^{M}\right)$, in which the upper index $(M)$ is the subset of the complete set of variables ( $V$ ). So in contrast to the general loglinear models, marginal log-linear models make it possible to control for only certain variables $(M-L)$ and not for all variables $(V-L)$.

Marginal log-linear models assume that certain effects are not that important and set those parameters equal to 0 , which means that one might omit them from the model. Therefore we gain a model that highlights the important associations. We validate statements concerning conditional independence.

${ }^{3}$ More about this topic can be found in Rudas and Bergsma (2004); Németh (2009); Rudas et al. (2006); Rudas et al. (2010), and Bergsma et al. (2009). This introduction is mostly based on Németh 2009. If we do not indicate otherwise then this is the source. 
$\mathrm{A}$ and $\mathrm{B}$ are conditionally independent from each other given $\mathrm{C}$ can be stated by the following formula:

$$
\lambda_{A B C}^{A B C}=\lambda_{A B}^{A B C}=0
$$

The goodness of fit of each model restriction can be tested by a likelihood ratio test $\left(G^{2}\right)$. If the model is true then these test statistics have an asymptotic Chi-square distribution. The degree of freedom in this case is equal the number of parameters which were set to 0 . If the P-value is smaller or equals 0.05 then the postulated model is rejected. Also we can test whether a model fits better than an alternative model. Let us assume that we have two nested models: M1 with $d f_{7}$ degrees of freedom and an alternative model M2 with $d f_{2}$ degrees of freedom which contains model M1 as a special case (M1 ᄃ M2). The conditional test statistic is then defined as

$$
\mathrm{G}^{2}(\mathrm{M} 1 \mid \mathrm{M} 2)=\mathrm{G}(\mathrm{M} 1)-\mathrm{G}^{2}(\mathrm{M} 2)
$$

and has an asymptotic Chi-square distribution with $d f=d f_{1}-d f_{2}$ if $\mathrm{Ml}$ is true (Bergsma et al. 2009).

The model that is used in this paper is directed acyclic graphs (DAG). One type of DAG is the path model. Path models assume that all hierarchical marginal log-linear parameters not associated with an arrow are zero (Rudas et al. 2006), so categorical path models can be obtained by setting higher than first-order effects to zero. This is a highly interpretable graph since arrows represent effects in these graphs. ${ }^{4}$

Finally, the analysis presented in this paper was conducted by the $\mathrm{cmm}$ package (Bergsma, 1997; Bergsma et al. 2009) of the R software (Németh, 2010).

\section{RESULTS}

A model was built in order to gain a more precise understanding of the relationship between gender and spillover. In order to do so, the following variables were included in this model:

- Spillover (S)

- Gender (G)

- Flexibility of work (F)

- Financial well-being (W)

- Age (A)

\footnotetext{
${ }^{4}$ For more on graphical models see Németh's (2009) PhD dissertation.
} 
In log-linear models the independence in a $3 \times 2$ contingency table can be tested by the observation of the model in which the interactional effect equals zero. If the $P$ value is bigger than 0.05 than we accept that the two variables are independent of each other. As Table 2 shows, gender, financial well-being and flexibility of work have a significant effect on spillover. The literature also deals with the age effect on spillover; however, in this study age was found to be independent from spillover. Because of this, age was excluded from our analysis.

Table 2: Testing independence of spillover and given independent variables

\begin{tabular}{lccc}
\hline Observed cross tables & Log likelihood ratio & df & P-value \\
\hline Spillover $\times$ Gender & 6.065 & 2 & 0.048 \\
Spillover $\times$ Flexibility of work & 6.679 & 2 & 0.035 \\
Spillover $\times$ Financial well-being & 14.998 & 2 & 0.001 \\
Spillover $\times$ Age & 4.867 & 6 & 0.561
\end{tabular}

Figure 1 shows how spillover differs by gender, financial well-being and flexibility of work: males, richer people and those whose job is more flexible reported more positive spillover.

Figure 1: Spillover by gender, financial well-being and flexibility of work

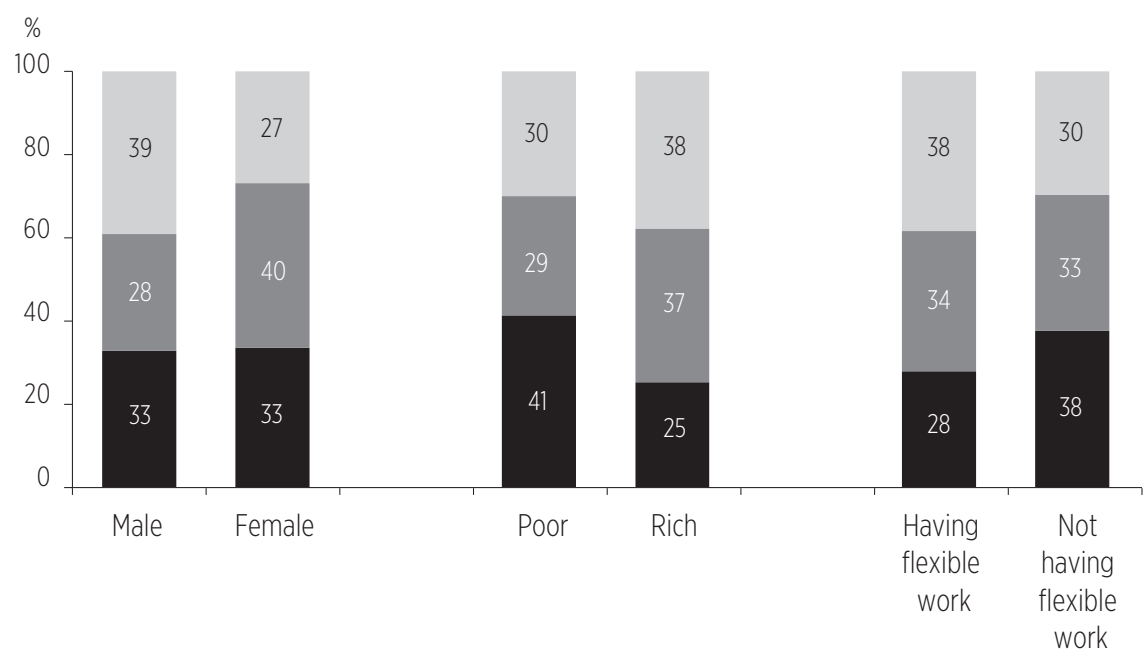

— Rather negative spillover — Avarage spillover _ Rather positive spillover 
Afterwards we tested to determine if gender is independent from spillover, controlling for flexibility of work and financial well-being. In other words, the following model (Model 1) has been tested:

$$
G \perp S \mid W F
$$

Table 3 shows that this model is appropriate since the P-value of the likelihood ratio test is 0.152 , which is higher than 0.05. Subsequently, the path model (Model 2) was tested to determine whether of not higher than first-order effects can be omitted. As Table 3 shows this model was also kept since the P-value of the likelihood ratio test is 0.165 . Finally, we also verified that the path model (Model 2) fits better than the model with higher interactions (Model 1). According to this test (more about this test in the methodology section) the path model can be kept since a significantly better model can be gained by omitting higher interactions.

Table 3: Selection of the best fitting model by testing a nested model

\begin{tabular}{ccccccccc}
\multicolumn{3}{c}{ Model 1 } & \multicolumn{3}{c}{ Model 2 } & \multicolumn{3}{c}{ Model 2 | Model 1} \\
$G^{2}$ & df & P-value & $G^{2}$ & df & P-value & $\Delta G^{2}$ & $\Delta$ df & P-value \\
11.966 & 8 & 0.152 & 15.374 & 11 & 0.165 & 3.408 & 3 & 0.333
\end{tabular}

Table 4 shows the good parametrization of the path model. ${ }^{5}$ In the first row of the table there are the marginals, the second row shows the parameters, which were set at 0 , and in the last row one can see the free parameters. The value of the free parameters will be predicted in the following section.

Table 4: Good parametrization of the path model

$\begin{array}{lcccc}\text { Marginal } & \text { G } & \text { NW } & \text { GWF } & \text { GWFS } \\ \text { Parameters which were set to } 0 & - & - & \text { GWF } & \text { GM, GFS, GWM, } \\ & & & & \text { WFS, GWFS }\end{array}$

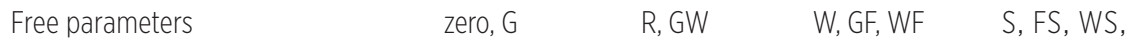

\footnotetext{
${ }^{5}$ For further reading about good parametrization: Rudas et al. (2006).
} 
Figure 2 shows the best fitting model by a graphical interpretation. This interpretation of the path model is straightforward. The vertexes represent variables (in Figure $2 \mathrm{G}$ is gender, $\mathrm{F}$ is flexibility of work, $\mathrm{W}$ is financial well-being and $\mathrm{S}$ is spillover). The absence of an arrow indicates conditional independence. An arrow between two vertices indicates a significant effect between two variables. This model demonstrates that spillover is conditionally independent of gender given financial situation and flexibility of work.

The graphical illustration of a path model also shows the predicted parameters on the arrow. Let's assume that a hypothetical graph has two vertices: $A$ and $B$. If $A$ and $B$ were binary variables then only the non-redundant parameters pertaining to the smaller values would be presented. While if $A$ or $B$ had three categories then each parameter would be given. A parameter estimate in the $i^{\text {th }}$ row and $j^{\text {th }}$ column of a matrix of the arrow $A B$ pertain to the $\boldsymbol{i}^{\text {th }}$ level of $A$ and the $j^{\text {th }}$ level of $B$. The asterisks ${ }^{*},{ }^{* *}$, and ${ }^{* * *}$ indicate significance at the $\mathrm{p}<0.05, \mathrm{p}<0.01$, and $\mathrm{p}<0.001$ levels, respectively.

For a better understanding of the predicted parameters on Figure 2 the categories of the variables need to be recalled. The variable for gender takes on a value of 1 if the respondent is male and 2 if the respondent is female. The variable for financial well-being takes on a value of 1 if the respondent is poor and 2 if the respondent is rich. The variable for flexibility of work takes on a value of 1 if the respondent has flexible work and a 2 if the person has no flexible work. Finally the spillover variable takes on a value of 1 if work has a negative effect on private life, a value of 2 if there is an average effect, and a 3 if there is a positive effect.

Figure 2: Parameter estimates for the path model

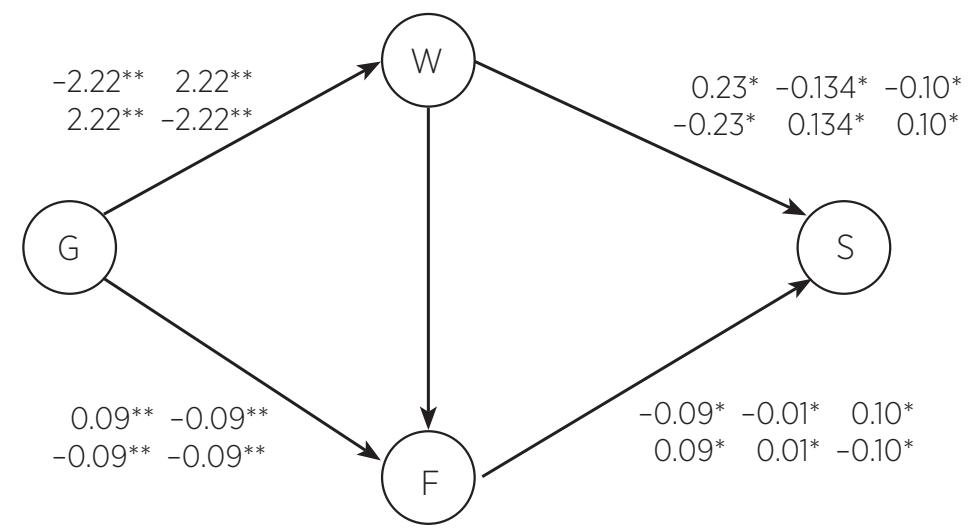

Notes: G - gender, F - flexibility of work, W - financial well-being, S - spillover; the asterisks *, ${ }^{* *}$ and ${ }^{* * *}$ indicate significance at the $p<0.05, p<0.01$ and $p<0.001$ levels, respectively. 
First, the relationship between gender $(G)$ and financial well-being $(W)$ has been observed. Figure 2 shows that $\lambda_{G W}^{G W}$ (Male, Poor) $=-2.22$, which means that males have a lower chance of being poor than females. After the analysis of gender and financial well-being, flexibility of work (F) can be seen in Figure 2 to show that $\lambda_{G F}^{G W F}$ (Male, HavingFlexibleWork)=0.09, meaning that males have more flexible work even after controlling for financial well-being. Since $\lambda_{W F}^{G W F}$ (Poor, HavingFlexibleWork)=-0.21 one can conclude that poor people have a lower chance of having a flexible job than rich people even after controlling for gender.

After analyzing the relationship between gender, financial well-being and flexibility of work, the spillover variable with the parameter $\lambda_{W S}^{G W F S}$ (Poor, NegativeSpillover) $=0.23$ shows that those who fall under the first category of well-being have a higher chance of falling under the first category of the spillover variable even after controlling for gender and flexibility of work. To put it differently, poor people have a higher chance of having negative spillover than rich people. This statement seems to be true even if we take into account that poor people tend to be female and have less chance of having flexible jobs, and at the same time being female or not having a flexible job increases the chance of negative spillover.

The relationship between flexibility of work and spillover was also examined. The parameter $\lambda_{F S}^{G W F S}$ (HavingFlexibleWork, NegativeSpillover) $=0.09$ shows that those who have a flexible job also tend to have a higher chance of having positive spillover after controlling for gender and financial well-being. This finding is in line with Jung Jang and colleagues' (2012) and Pedersen and Jeppesen's (2012) argument, and does not support those who found an inverse relationship between flexibility and spillover (e.g. Fursman and Zodgekar, 2009; Joyce et al. 2010).

To sum up, on average women have a significantly lower probability of having a job that has a positive effect on their family life than an average man. This study has shown, however, that gender is conditionally independent of spillover given the financial status and flexibility of work. This is because women have a lower chance of reporting better financial well-being and having a flexible job while this analysis demonstrates that being rich and working in a flexible job increase the chance of having positive spillover. The authors argue, therefore, that the relative disadvantages females face in terms of spillover can be primarily attributed to their reported financial status and their relatively low access to more flexible jobs. 


\section{DISCUSSION}

In this paper we have analyzed the data in order to trace a new dimension of gender inequality, namely inequality in work-to-family spillover. The data has been analyzed in an exploratory manner by utilizing marginal log linear models. To sum up the most important findings, the results show that spillover effects are present among the economically active members of the Hungarian society. This would indicate that the spillover theory also has validity in a CEE context. This finding is in line with former research results (Grzywacz et al. 2007; Powell and Greenhaus, 2010) showing the dominance of spillover 'strategy'.

This paper also investigated the factors of the inequality described above. It has been pointed out that gender differences in spillover can be explained by perceived financial well-being and the (voluntary) flexibility of work. So, one can argue that the spillover phenomenon projected to a positive-negative continuum can represent a new dimension of gender inequalities alongside these 'traditional' forms of disparities. Our analysis has made it clear that gender inequality is driven and maintained by various social inequalities, such as access to flexibility at work or financial well-being. To begin with, the findings have supported that men have better subjective financial well-being. Also, it can be determined from the analysis that, by controlling for the variable of subjective financial well-being, men are more likely to experience (voluntary) flexibility in their work, meaning they feel that they have greater control over their working conditions. In the model both financial well-being and flexibility of the job have an effect, so both are essential in understanding and explaining gender differences. This is an important result because, among others results, Pedersen and Jeppesen (2012) underlined that flexibility enhances employees' success in finding work-life balance and managing borders between private and working life.

Two other issues are worth mentioning in relation to our results. First, it is noteworthy that financial well-being has such a significant effect in mediating the role of spillover in one's life. Tentatively, it can be said that this might be due to the importance of financial and material issues in people's well-being in Hungary in particular and in post-socialist countries in general (Fodor and Nagy, 2014). Prior studies have written about the high frequency of material deprivation in the CEE countries, and that poverty increased considerably in this region due to the 2008 recession. Although the crisis was a 'man-cession', women's poverty has become more widespread both during the crisis as well as 
during the austerity period (Fodor and Nagy, 2014). This gives special emphasis to the main result of this paper, namely, that the differences relating to the experience of spillover effects in one's life are not individual phenomena but are embedded in the broader social context of inequalities.

Secondly, in line with the literature on the relationship of flexibility and the spillover effect, it can be argued that it is not enough to examine flexible working conditions in themselves since there are more than one type of 'flexibilities', e.g. unsocial working hours, forced or badly paid part-time work, overwork, thus there is an urgent need for the critical analysis of flexibility. In this respect one must clearly explore whose flexibility, i.e. employees' or organizations' flexibility is the most challenging in the labor market. The results of this paper demonstrate the fact that those groups can benefit greatly from flexible working conditions whose initial social situation (i.e. financial well-being) is also better (which most probably also represents higher positions in organizational hierarchies). These findings point to the fact that differences in the social situation of the respondents, in turn, reinforce gender inequalities (i.e. men tend to have better financial well-being) related to how men and women experience spillover effects in their lives.

The issue of gender differences has always been an important aspect in the analyses of work-life balance in general, and spillover investigations in particular (Keene and Reynolds, 2005; Offer, 2014; Powell and Greenhaus, 2010). The present findings, however, might offer new contributions to the academic discussion on the topic, as they clearly point to structural biases of the labor market. The less favorable work-to-family spillover status of women can be explained by their restricted access to (advantageous or voluntary) flexible jobs, and also by their underrepresentation in more well-paying jobs. These results, while being consistent with earlier findings, subtly affect our understanding of work-life spillover, as far as gender differences involved in spillover effects are concerned. It is important to mention that these quantitative results are also in line with the qualitative findings of Primecz and colleagues (2014), pointing to the fact that differences of gender and organizational positions might affect and reinforce each other.

These findings raise interesting questions for future research initiatives. First of all, in the CEE context, it is very likely that different factors play key roles in mediating spillover effects than those identified in the predominantly AngloSaxon literature. For example, financial well-being plays a critical role in Hungary, while previous analyses tended to pay less attention to this factor (Jung Jang 
et al. 2012; Lourel et al. 2009; Powell and Greenhaus, 2010). In addition to these findings, here are also signs that the accustomed dichotomy of inflexible working conditions for males vs. more flexible working conditions limited to females alone might not be so straightforward in the post-socialist context. Our results show that men actually have a higher chance of obtaining flexible working conditions, good or voluntary, after controlling for the financial situation. In contrast flexible work arrangements in general are more widespread among women in Western European countries, as mentioned in the Hungarian context section. In Hungary, instead of flexibility, these labor markets are characterized more by 'rigidity'. It means that the positive effect of flexibility is experienced by a chosen few - in other words, the privileged parts of the working population. It is important to mention that the analysis in this paper is based on schedule and job location flexibility. A future research aspiration that it would be important to examine is the other side of the flexibility phenomenon - involving involuntary part-time employment, fixed term contracts and the relationship to gender and spillover effects.

These possible explanations could be investigated in an international research project including the factors used in this particular study, as well as those habitually analyzed in studies on spillover effects. Our research focused only on the work-to-family direction of spillover effects. Since these results suggest that factors such as flexibility play a different role in a post-socialist context than they did in the old member states (see Hungarian context section), it is worth examining the other direction - the family-to-work effect - as well. This dataset also made it possible for us to investigate the affective part of spillover (feelings, stress or intrusion of work-related ideas), whereas the instrumental aspects could not be explored sufficiently. Finally, the analysis demonstrates the need to focus on the possible relationship of crossover and spillover effects among parents and their children. 


\section{APPENDIX}

Table 1: Components of spillover (both positive and negative)

\begin{tabular}{ll} 
Affective & Mood (happiness) \\
& Attitudes \\
\hline \multirow{3}{*}{ Instrumental } & Values (e.g. diversity) \\
& Skills (e.g. Excel) \\
& Behaviour (e.g. ethical acting)
\end{tabular}

Based on: Greenhaus and Powell, 2006; Powell and Greenhaus, 2010, pp.518-519.

Table 2: Distribution of the independent variables in the working population (\% and number of cases)

\begin{tabular}{|c|c|c|}
\hline Variables & Categories & $\%(n)$ \\
\hline \multirow{2}{*}{ Gender } & Male & $55.6(286)$ \\
\hline & Female & $44.4(228)$ \\
\hline \multirow[b]{2}{*}{ Financial well-being } & $\begin{array}{l}\text { Those who have financial } \\
\text { problems or whose salary is } \\
\text { just enough to survive }\end{array}$ & $48.0(246)$ \\
\hline & $\begin{array}{l}\text { Those who get on well by } \\
\text { planning ahead or even } \\
\text { without that }\end{array}$ & $52.0(266)$ \\
\hline \multirow{2}{*}{$\begin{array}{l}\text { Flexibility of work (working time } \\
\text { or working place) }\end{array}$} & Having a flexible job & $46.1(236)$ \\
\hline & Not having a flexible job & $53.9(276)$ \\
\hline
\end{tabular}


Table 3: Distribution of financial well-being by gender (\% and number of cases)

$\begin{array}{lll} & \begin{array}{l}\text { Those who have financial } \\ \text { problems or whose salary is } \\ \text { just enough to survive }\end{array} & \begin{array}{l}\text { Those who get on well by } \\ \text { planning ahead or even } \\ \text { without that }\end{array} \\ \text { Male } & 46.5(113) & 53.5(153) \\ \text { Female } & 50.0(113) & 50.0(113)\end{array}$

Table 4: Distribution of flexible job by gender and financial well-being (\% and number of cases)

\begin{tabular}{llll} 
& & Having a flexible job & $\begin{array}{l}\text { Not having a flexible } \\
\text { job }\end{array}$ \\
\hline \multirow{2}{*}{ Gender } & Male & $50.9(145)$ & $49.1(140)$ \\
& Female & $40.1(91)$ & $59.9(136)$ \\
\hline Financial well-being & $\begin{array}{l}\text { Those who have } \\
\text { financial problems } \\
\text { or whose salary } \\
\text { is just enough to } \\
\text { survive }\end{array}$ & $35.8(88)$ & $64.2(158)$ \\
& $\begin{array}{l}\text { Those who get on } \\
\text { well by planning } \\
\text { ahead or even } \\
\text { without that }\end{array}$ & $56.2(149)$ & \\
\hline
\end{tabular}




\section{REFERENCES}

Bergsma, W. P. (1997). Marginal models for categorical data. Tilburg: Tilburg University Press. http://stats.lse.ac.uk/bergsma/pdf/bergsma_phdthesis.pdf.

Bergsma, W. P., Croon, M. A. and Hagenaars, J. A. (2009). Marginal models for dependent, clustered and longitudinal categorical data. New York: Springer.

Csillag, M. (2007). "Female work" and the gender pay gap from late socialism to today. In: Fazekas, K., Kézdi G., eds. The Hungarian Labour Market. Budapest: Institute of Economics, Hungarian Academy of Sciences, pp.97-103.

Dén-Nagy, I. (2013). Az infokommunikációs technológiák munka-magánélet egyensúly megteremtésében játszott szerepe - Elméleti áttekintés. [The Role of Information and Communication Technologies in Reaching Work-Family Balance - Theoretical Overview.], socio.hu, 3(1), pp.1-21. http://socio.hu/uploads/files/2013_3/1den_nagy.pdf.

Edwards, J. R. and Rothbard, N. P. (2000). Mechanisms Linking Work and Family: Clarifying the Relationship between Work and Family Constructs. The Academy of Management Review, 25(1), pp.178-199.

Eurostat (2015a). Employment (main characteristics and rates) - annual averages. Code: Ifsi_emp_a. http://ec.europa.eu/eurostat/product?code=Ifsi_

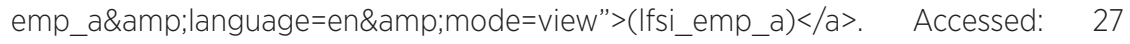
January 2016.

Eurostat (2015b). Employment (main characteristics and rates) - annual averages. Code: Ifsa_eppga. http://ec.europa.eu/eurostat/product?code=lfsa_ eppga\&amp;language=en\&amp;mode=view" $>(\mid$ Ifsa_eppga)</a>. Accessed: 27 January 2016.

Fodor, É. and Nagy, B. (2014). "An Ebbing Tide Lowers all Boats": How the Great Recession of 2008 has Affected Men and Women in Central and Eastern Europe. In: A. Eydoux, A. Math and H. Périvier, eds., European labour markets in times of crisis: A gender perspective. Special Issue of the French Economic Observatory review (OFCE review, Revue 133), pp.121-152. www.ofce.sciences-po.fr/publications/revue133.htm.

Fursman, L. and Zodgekar, N. (2009). Making It Work: The Impacts of Flexible Working Arrangements on New Zealand Families. Social Policy Journal of New Zealand, 35, pp.43-54.

Greenhaus, J. H. and Beutell, N. J. (1985). Sources of conflict between work and family roles. Academy of Management Review, 10(1), pp.76-88.

Greenhaus, J. H. and Powell, G. N. (2006). When Work and Family Are Allies: A Theory of Work-Family Enrichment. Academy of Management Review, 31(1), pp.72-92.

Grzywacz, J. G. et al (2007). A multi-level perspective on the synergies between work and family. Journal of Occupational and Organizational Psychology, 80(4), pp.559-574. DOI:10.1348/096317906×163081

Hanson, G. C., Hammer, L. B. and Colton, C. L. (2006). Development and validation of a multidimensional scale of perceived work-family positive spillover. Journal of Occupational Health Psychology, 11, pp.249-265.

Hárs, Á. and Neumann, L. (2008). Telework in Hungary. http://www.eurofound.europa.eu/ observatories/eurwork/articles/telework-in-hungary. Accessed: 1 October 2016. 
Ilies, R., Wilson, K. S. and Wagner, D. T. (2009). The spillover of daily job satisfaction onto employees' family lives: the facilitating role of work-family integration. Academy of Management Journal, 52(1), pp.87-102.

Joyce, K., Pabayo, R., Critchley, J. A. and Bambra, C. (2010). Flexible working conditions and their effects on employee health and wellbeing. The Cochrane Database of Systematic Reviews, 2, CD008009. http://doi.org/10.1002/14651858.CD008009.pub2.

Jung Jang, S., Zippay, A. and Park, R. (2012). Family Roles as Moderators of the Relationship between Schedule Flexibility and Stress. Journal of Marriage and Family, 74(4), pp.897-912.

Keene, J. R. and Reynolds, J. R. (2005). The Job Costs of Family Demands: Gender Differences in Negative Family-to-Work Spillover. Journal of Family Issues, 26(3), pp.275-299.

Király, G., Nagy, B., Géring, Zs., Radó, M., Lovas, Y. and Pálóczi, B. (2015). Spillover: Empirical utilization of the concept: An overview of the social scientific corpus from 2004 to 2014. Corvinus Journal of Sociology and Social Policy, 6(2), pp.93-116. DOI: 10.14267/cjssp.2015.02.05

Lourel, M., Ford, M. T., Gamassou, C. E., Guéguen, N. and Hartmann, A. (2009). Negative and positive spillover between work and home: Relationship to perceived stress and job satisfaction. Journal of Managerial Psychology, 24(5), pp.438-449. http://doi. org/10.1108/02683940910959762

Medgyesi, M. (2001). Households, Work and Flexibility: literature review. Hungary. TÁRKI, Research Report. http://www.tarki.hu/adatbank-h/kutjel/pdf/a211.pdf. Accessed: 1 October 2016.

Németh, R. (2009). Discrete Graphical Models in Social Mobility Research (Grafikus modellek társadalomtudományi alkalmazása mobilitási adatokon). PhD dissertation, ELTE Doctoral School of Sociology.

Németh, R. (2010). Log-linear models in SPSS \& Marginal log-linear and graphical models in R. http://nemethr.web.elte.hu/LoglinMargGraph/. Accessed: 10 March 2013.

Offer, S. (2014). The Costs of Thinking about Work and Family: Mental Labor, Work-Family Spillover, and Gender Inequality Among Parents in Dual-Earner Families. Sociological Forum, 29(4), pp.916-936. http://doi.org/10.1111/socf.12126

Pedersen, V. B. and Jeppesen, H. J. (2012). Contagious flexibility? A study on whether schedule flexibility facilitates work-life enrichment. Scandinavian Journal of Psychology, 53(4), pp.347-359 http://doi.org/10.1111/j.1467-9450.2012.00949.x

Plantenga, J. and Remery, Ch. (2009). Flexible working time arrangements and gender equality, A comparative review of 30 European countries. European Commission Directorate - General for Employment, Social Affairs and Equal Opportunities Unit G1.

Powell, G. N. and Greenhaus, J. H. (2010). Sex, Gender, and the Work-to-Family Interface: Exploring Negative and Positive Interdependencies. Academy of Management Journal, 53(3), pp.513-534. http://doi.org/10.5465/AMJ.2010.51468647

Primecz, H., Kiss, Cs., Toarniczky, A., Csillag, S., Szilas, R., Bácsi, K. and Milassin, A. (2014). Magyarországi „munkavállaló-barát” (employee friendly) szervezetek - Valóság vagy utópia (avagy mit tanulhatunk tőlük?). Vezetéstudomány, 45(10), pp.2-16. 
Rantanen, J. (2008). Work-Family Interface and Psychological Well-Being. A Personality and Longitudinal Perspective. University of Jyväskylä, Jyväskylä Studies in Education, Psychology and Social Research 346. https://jyx.jyu.fi/dspace/bitstream/ handle/123456789/19200/9789513934255.pdf?sequence=1. Accessed: 1 March 2015.

Roehling, P., Moen, P. and Batt, R. (2003). Spillover. In: P. Moen, ed., It's about time: Couples and careers. Ithaca, NY: Cornell University Press, pp.101-121.

Róbert P. (2008). Vélemények és attitüdök a munkavégzésről. Időbeli változás és nemzetközi összehasonlitás. [Opinions and attitudes on wage work. Changes over time and an international comparison.] OTKA T46648. Final report.

Rudas, T. and Bergsma, W. P. (2004). On Applications of Marginal Models to Categorical Data. Metron, 42, pp.15-37.

Rudas, T., Bergsma, W. P. and Németh, R. (2006). Parameterization and estimation of path models for categorical data. In: A. Rizzi and M. Vich, eds., COMPSTAT 2006. Proceedings in Computational Statistics. Heidelberg: Physica, pp.383-394.

Rudas, T., Bergsma, W. P. and Németh, R. (2010). Marginal log-linear parameterization of conditional independence models. Biometrika, 97(4), pp.1006-1012.

Tammelin, M. (2009). Working time and family time. Experiences of the Work and Family Interface among Dual-Earning Couples in Finland. University of Jyväskylä, Jyväskylä Studies in Education, Psychology and Social Research, 355, https://jyx.jyu.fi/dspace/ bitstream/handle/123456789/19730/9789513935160.pdf. Accessed: 1 March 2015.

TÁRKI (2010). Working time flexibility, work-family conflict and social cohesion. Research report. http://workcaresynergies.eu/wp-content/uploads/2010/05/WCS_TARKI_ DM1_EN.pdf. Accessed: 1 October 2016. 